\title{
Nilai-Nilai Kewirausahaan Dan Komitmen Berwirausaha Terhadap Kinerja UMKM dengan Strategi Bisnis Sebagai Moderasi
}

\author{
Submitted Date: \\ 23 Desember 2020 \\ Accepted Date: \\ 8 Februari 2021
}

Titiek Ambarwati
ammadiyah Malang

Universitas Muhammadiyah Malang
ambarwati.titiek@gmail.com

Fika Fitriasari

Universitas Muhammadiyah Malang

fika@umm.ac.id

\section{Suggested Citation:}

Batista, P. C. de S., Lisboa, J. V. de O., Augusto, M. G., \& Almeida, F. E. B. de. (2016). Effectiveness of business strategies in Brazilian textile industry. Revista de Administração [RAUSP], 51(2), 225-239.

\begin{abstract}
This study aims to determine the application of the main entrepreneurial values of achievement motivation and self efficacy on business performance mediated by business commitment as moderating strategy as a moderating variable. This research uses quantitative research and the type of research is explanatory research. Respondents of this study were 70 UMKM entrepreneurs in Lowokwaru, Malang City. The technique of collecting data using a questionnaire. The data analysis technique used is Partial Least Square (PLS). The results show that achievement motivation has no effect on entrepreneurial commitment, research efficacy has a significant effect on entrepreneurial commitment, entrepreneurial commitment does not mediate achievement motivation on business performance, entrepreneurial commitment mediates the effect of self-efficacy on business performance, and business strategy does not moderate the effect of entrepreneurial commitment on business performance. Future research can use other variables such as intention in entrepreneurship with a wider scope of MSMEs.
\end{abstract}

Keywords: achievement motivation, business performance, business strategy, entrepreneurial commitment, self-efficacy

Abstrak

Penelitian ini bertujuan untuk mengetahui penerapan nilai-nilai kewirausahaan utamanya motivasi berprestasi dan efikasi diri terhadap kinerja usaha yang dimediasi oleh komitmen berwirausaha dan strategi bisnis sebagai moderasi dengan strategi bisnis sebagai variabel moderasi. Penelitian ini menggunakan pendekatan kuantitatif dan jenis penelitian adalah explanatory research. Responden penelitian ini adalah 70 pengusaha UMKM di Kelurahan Lowokwaru, Kota Malang. Teknik Pengumpulan data dengan menggunakan kuisioner. Teknik analisis data yang digunakan adalah Partial Least Square (PLS). Hasil penelitian menunjukkan bahwa motivasi berprestasi berpengaruh tidak signfikan terhadap komitmen berwirausaha, efikasi diri berpengaruh signifikan terhadap komitmen berwirausaha, komitmen berwirausaha tidak memediasi pengaruh motivasi berprestasi terhadap kinerja usaha, komitmen berwirausaha memediasi pengaruh efikasi diri terhadap kinerja usaha, strategi bisnis tidak memoderasi pengaruh komitmen berwirausaha terhadap kinerja usaha. Penelitian selanjutnya dapat menggunakan variabel lain seperti intensi dalam berwirausaha dengan lingkup UMKM yang lebih luas.

Kata Kunci efikasi diri, kinerja usaha, komitmen berwirausaha, motivasi berprestasi, strategi bisnis

\section{JEL Classification: L26}




\section{Latar Belakang}

Persaingan dalam dunia kerja serta permasalahan dalam tenaga kerja yang menyebabkan adanya pengangguran, menjadikan masyarakat dituntut untuk berpikir kreatif dan inovatif serta membuka lapangan pekerjaan dengan membuat sebuah usaha. Berwirausaha menjadi salah satu alternatif yang dilakukan bagi masyarakat dan menjadi sesuatu yang penting dalam memberikan pilihan untuk membuka lapangan pekerjaan (Azhar et al., 2014). Fenomena berwirausaha tidak hanya terjadi pada seseorang yang tidak mendapatkan pekerjaan, tetapi juga berawal dari seorang karyawan yang sudah bekerja pada suatu organisasi dan memutuskan untuk keluar dan menjadi seorang wirausaha (Darmawan, 2020). UMKM menjadi salah satu alternatif bagi para wirausaha dalam menjalankan usahanya.

UMKM adalah usaha produktif yang dimiliki peseorangan atau badan usaha yang memenuhi kriteria sebagai usaha mikro. Mayoritas UMKM mengandalkan sumber pembiayaan non-perbankan dalam aspek pendanaan usaha. UMKM cenderung lebih fleksibel dalam memilih dan berganti jenis usaha. UMKM membantu perekonomian Indonesia karena mampu membentuk lapangan kerja baru serta meningkatkan devisa negara melalui pajak badan usaha. Kelebihan adanya UMKM adalah pemilik bebas bertindak dan mengambil keputusan, pemilik umumnya memiliki peran secara langsung dalam menjalankan usaha dan setiao usaha yang dijalankan sesuai dengan kebutuhan masyarakat setempat. Namun dibalik itu, UMKM juga memiliki kekurangan yang salah satunya sulit mengembangkan usaha karena modal yang terbatas. Sebuah UMKM disebut berhasil menurut Riyanti (2006) ketika memiliki peningkatan modal, jumlah produksi, jumlah pelanggan, perluasan usaha, perluasan daerah pemasaran, perbaikan sarana fisik dan peningkatan pendapatan usaha.

Perkembangan Usaha Mikro, Kecil, Menengah (UMKM) di Negara Indonesia menunjukkan pola yang cukup baik. Pemerintah mendukung melalui cara-cara tertentu, sehingga mempengaruhi angka pertumbuhan jumlah unit usaha mikro, kecil, dan menengah. UMKM memiliki peran yang cukup besar dalam peningkatan penyerapan tenaga kerja, pembentukan produk domestik bruto (PDB), dan penyediaan jaring pengaman khususnya bagi masyarakat yang terimbas krisis keuangan dan ekonomi. Kontribusi UMKM dalam penciptaan (PDB) pada tahun 2018 mencapai 14.038.598,5 (dalam milyar). UMKM secara keseluruhan menunjukkan perkembangan dan pertumbuhan dari tahun ke tahun. Data dari Kementerian Koperasi dan UKM RI menunjukan, pada 2014, jumlah UMKM sebanyak 57.900.787. Lalu jumlahnya meningkat menjadi 64.199 .606 pada 2018 (Kementrian Koperasi dan Usaha Kecil dan Menengah, 2018).

UMKM memiliki kemampuan untuk melakukan inovasi dan memberikan banyak peluang untuk pengembangan teknologi yang mampu mengembangkan unit-unit kecil. Keberhasilan dan keberlangsungan UMKM tidak lepas dari seorang pemilik. Pemilik UMKM yang juga sebagai pemimpin memiliki kontribusi dan peran penting untuk kemajuan UMKM. Adanya keinginan yang kuat dalam mengembangkan usaha, dan memiliki dorongan agar sukses menjalankan usaha merupakan sebuah cita-cita yang diharapkan oleh seorang pemilik. Dengan adanya dorongan yang kuat dalam menjalankan usaha, maka akan memunculkan motivasi berprestasi, khususnya dalam UMKM. Selain itu, adanya motivasi juga akan mempengaruhi dan meningkatkan kepercayaan diri mengenai kemampuan yang dimiliki, yang disebut efikasi diri. Efikasi diri dan motivasi berprestasi merupakan komponen utama dalam nilai-nilai kewirausahaan dalam meningkatkan kinerja, baik kinerja karyawan maupun kinerja usaha. Kinerja usaha akan mengalami peningkatan, seiring dengan adanya penerapan nilai-nilai kewirausahaan bagi pemilik UMKM. Keberlangsungan UMKM akan bergantung dengan kinerja UMKM yang telah dicapai.

Kinerja usaha merupakan suatu kondisi yang harus diketahui dan dikonfirmasikan kepada pihak tertentu untuk mengetahui tingkat pencapaian hasil suatu instansi dihubungkan dengan visi yang diemban suatu organisasi atau perusahaan serta mengetahui dampak positif dan negatif dari suatu kebijakan operasional (Lubis et al., 2018). Ada tolak ukur dalam mencapai kinerja usaha seperti keuntungan yang didapatkan, volume penjualan dan pangsa pasar (Najib \& Kiminami, 2011).Selain itu, adanya dorongan dan motivasi dalam berwirausaha juga menjadi salah satu pedoman dalam meningkatkan kinerja usaha. Namun, dalam meningkatkan kinerja usaha atau UMKM memerlukan dorongan dan adanya tekad yang kuat dalam melakukan wirausaha, yaitu komitmen berwirausaha. Komitmen berwirausaha merupakan suatu keterikatan diri dan keinginan yang kuat untuk membangun, memajukan, dan mempertahankan keberadaan usahanya dalam situasi apapun. Adanya komitmen yang kuat, maka akan mendorong untuk melakukan yang terbaik bagi usahanya, agar usaha yang dilakukan memiliki hasil yang maksimal.

Terdapat beberapa penelitian yang meneliti tentang adanya pengaruh nilai-nilai kewirausahaan terhadap komiten berwirausaha. (Lu, Siu, \& Cooper, 2005) menyatakan adanya pengaruh sikap, perilaku, dan motivasi berprestasi terhadap komitmen berwirausaha. Factor-faktor tersebut memiliki peranan dalam menumbuhkan 
komitmen berwirausaha pada pemilik usaha. Adanya dorongan yang kuat dalam mencapai keinginan akan keberhasilan dalam suatu usaha akan meningkatkan keinginan yang kuat untuk selalu memberikan yang terbaik bagi unit usahanya. Dinis et al., (2013) menjelaskan mengenai karakteristik kewirausahaan yang salah satunya menjelaskan mengenai motivasi berprestasi. Penelitian tersebut menjelaskan seseorang yang mempunyai motivasi berprestasi yang lebih tinggi daripada orang lain dan mempunyai hubungan yang kuat dalam niat berwirausaha.

Selain motivasi berprestasi, efikasi diri merupakan salah satu komponen penting pada nilai-nilai kewirausahaan. Efikasi diri memiliki peranan dalam pengembangan sebuah usaha (Bagheri et al., 2013). Efikasi diri merupakan keyakinan atau kepercayaan diri atas kemampuannya dalam mewujudkan suatu tujuan tertentu (Wulandari, 2013). Dengan memiliki efikasi diri yang tinggi dan meyakini akan kemampuannya dalam mencapai target usaha yang ditetapkan, maka juga akan meningkatkan komitmen yang kuat dalam berwirausaha. Fortune, Lee, \& Cavazos (2005) menyatakan bahwa efikasi diri yang tinggi berpengaruh signifikan terhadap komitmen berwirausaha. Kuatnya komitmen berwirausaha, dipengaruhi oleh adanya efikasi diri pada pemilik.

Kota Malang adalah kota terbesar kedua di Jawa Timur yang memiliki beragam destinasi wisata dan keunikan yang menjadi ciri khas di kota Malang. UMKM di Kota Malang sangat beragam baik di bidang fashion, makanan minuman sampai dengan kerajinan tangan (crafting). Menurut data dari Dinas Koperasi dan UMKM kota Malang terdapat lebih dari 70.000 UMKM yang tersebar pada tahun 2019. UMKM masih mengalami banyak kendala yang berkaitan dengan rendahnya nilai- nilai kepribadian kewirausahaan yang didasarkan pada motivasi berprestasi, efikasi diri, komitmen berwirausaha, dan kinerja usaha dapat berimplikasi dengan kurang berkembangnya usaha kecil. Kendala yang lain adalah rendahnya kapasitas dan kualitas sumber daya manusia yang rendah, keterbatasan akses kepada sumber daya produktif (modal, bahan baku, informasi, pengetahuan, keterampilan dan teknologi), serta tingginya biaya transaksi. Kendala-kendala tersebut menyebabkan UMKM yang masih didominasi oleh usaha mikro sulit untuk tumbuh menjadi usaha yang lebih besar ("naik kelas"), atau bertahan dengan usaha produktif yang berkelanjutan (Hakim, 2019).

Kinerja atau prestasi yang dicapai melalui kemampuan kreativitas dan inovasi dalam menghasil ide-ide atau produk-produk baru dihasilkan dari seseorang yang berorientasi pada nilai-nilai kewirausahaan ditunjukkan melalui sifat atau ciri, antara lain: motivasi berprestasi, efikasi diri, dan komitmen yang kuat. Selain nilai-nilai kewirausahaan, penerapan strategi bisnis meliputi strategi kepemimpinan biaya, strategi differensiasi, dan strategi fokus yang tepat juga diperlukan untuk meningkatkan kinerja UMKM di Kota Malang. Kajian empiris terkait hubungan penerapan strategi dengan kinerja Usaha Kecil Menengah sudah dilakukan Hakimpoor (2014)) secara spesifik terkait hubungan dengan kinerja pasar (Ebitu \& Ezekiel, 2016; Kimatu \& Bichanga, 2014). Kajian tersebut membuktikan bahwa penerapan strategi mempengaruhi peningkatan UKM, strategi yang digunakan berbagai macam mulai dari strategi perencanaan, formulasi, orientasi strategi, capability strategi, strategi marketing, strategi generik dan lainnya. Berdasarkan penjelasan tersebut timbul suatu pertanyaan strategi apa yang tepat di gunakan dan diterapkan oleh UKM agar kinerja UKM meningkat.

Lingkungan dan perubahan lingkungan eksternal perusahaan sangat mempengaruhi perkembangan Usaha kecil dan menengah (Nyariki, 2013). Contoh perubahan lingkungan eksternal adalah perubahan teknologi maupun informasi, faktor ekonomi, faktor sosial, dan kreatifitas produk memberikan variasi produk yang sangat cepat. Jika penerapan strategi bisnis yang digunakan oleh para manajemen kurang sesuai dengan perubahan lingkungan yang terjadi. Maka, diperlukan evaluasi dan penerapan strategi baru agar perusahaan mampu bersaing lebih kompetitif. Selain itu penerapan strategi perlu disesuaikan dengan karakteristik pada UKM yang mereka miliki karena apabila salah dalam pemilihan dan penerapannya akan mendapatkan potensi kerugian (Kaya, 2015). Agar UKM dapat menghasilkan profit yang besar dan memiliki keunggulan bersaing maka identifikasi strategi kompetitif harus di lakukan (Batista, Lisboa, Augusto, \& Almeida, 2016). Penelitian ini memberikan informasi tentang nilai-nilai kewirausahaan, komitmen berwirausaha dan strategi bisnis yang di terapkan para pengusaha UMKM Kota Malang dalam menghadapi persaingan dengan usaha sejenis lainnya dan bagaimana pengaruhnya sehingga penelitian ini penting dilakukan. Adapun tujuan penelitian ini adalah sebagai untuk mengetahui pengaruh Motivasi berprestasi terhadap komitmen berwirausaha, untuk mengetahui pengaruh efikasi diri terhadap komitmen berwirausaha, untuk mengetahui pengaruh motivasi berprestasi dan efikasi diri terhadap kinerja usaha dengan komitmen berwirausaha sebagai variabel mediasi, untuk mengetahui pengaruh komitmen berwirausaha terhadap kinerja usaha, untuk mengetahui peran strategi bisnis sebagai moderasi antara komitmen berwirausaha dengan kinerja. 


\section{Literature Review}

\section{Nilai-Nilai Kewirausahaan}

Nilai-nilai kewirausahaan penting diterapkan dan dilakukan oleh pemiliki usaha guna keberlangsungan dan kemajuan UMKM maupun usaha lain yang dijalankan. Nilai-nilai kewirausahaan merupakan prasyarat yang berhubungan dengan perilaku kewirausahaan (Kickul \& Gundry, 2002). Nilai adalah suatu keyakinan abadi dan suatu cara bertindak yang khas bertindak atau tujuan hidup yang bertentangan atau berlainan. Nilai menyangkut watak dan sifat yaitu: percaya diri, berorientasi pada tugas dan keberhasilan, Pengambil risiko, Kepemimpinan, keorisinilan yang tercermin, dan berorientasi ke masa depan. Sahabudin (2012) menyatakan nilai-nilai kewirausahaan yang terdiri dari komitmen berwirausaha memiliki kontribusi pengaruh yang dominan dari motivasi berprestasi dan efikasi diri terhadap kinerja usaha, baik langsung maupun tidak langsung melalui komitmen berwirausaha. Efikasi diri dapat mendorong kinerja seseorang dalam berbagai bidang termasuk minat berwirausaha (Luthans, 2006). Oleh karena itu, dalam membuka suatu usaha diperlukan keyakinan diri (selfefficacy) terhadap kemampuannya agar usahanya dapat berhasil. Hal yang sama juga diungkapkan oleh Robbins \& Judge (2015) dimana efikasi diri juga dikenal dengan teori kognitif sosial atau penalaran sosial yang merujuk pada keyakinan individu bahwa dirinya mampu menjalankan suatu tugas.

Zimmerer et al. (2009) mengartikan kewirausahaan sebagai suatu proses penerapan kreativitas dan inovasi dalam memecahkan persoalan dan menemukan peluang untuk memperbaiki kehidupan utamanya dalam usaha. Sedangkan Kasmir (2017) menguraikan kewirausahaan merupakan suatu kemampuan dalam hal menciptakan kegiatan usaha. Kemampuan menciptakan memerlukan adanya kreativitas dan inovasi yang terus-menerus untuk menemukan sesuatu yang berbeda dari yang sudah ada sebelumnya. Kreativitas dan Inovasi tersebut pada akhirnya mampu memberikan kontribusi bagi masyarakat banyak.

Suryana (2017) menyatakan ciri-ciri umum kewirausahaan dapat dilihat dari beberapa aspek kepribadian seperti jiwa, watak, sikap, dan perilaku seseorang. Ciri-ciri kewirausahaan meliputi enam komponen penting yaitu: Percaya diri dan optimis, memiliki kepercayaan diri yang kuat, ketidakbergantungan terhadap orang lain, dan individualistis; Berorientasi pada tugas dan hasil, kebutuhan untuk berprestasi, berorientasi pada laba, mempunyai dorongan kuat, energik, tekun dan tabah, bertekad kerja keras serta inisiatif; Berani mengambil risiko dan menyukai tantangan, yaitu mampu mengambil risiko yang wajar; Kepemimpinan, berjiwa kepemimpinan, mudah beradaptasi dengan orang lain, dan terbuka terhadap saran dan kritik; Keorisinalitasan, yaitu inovatif, kreatif, dan fleksibel; dan Berorientasi masa depan, memiliki visi dan prespektif terhadap masa depan. Selain itu nilai-nilai dan perilaku kewirausahaan ditinjau dari komitmen, resiko moderar dengan melakukan berdasar perhitungan yang matang, melihat peluang, objektivitas, adanya umpan balik, optimisme. Nilai-nilai kewirausahaan juga terdiri atas kreativitas, pengambilan risiko, inovasi, berorientasi prestasi, ambisi (Boohene et al., 2008).

\section{Komitmen Berwirausaha}

Komitmen adalah perjanjian atau keterikatan untuk melakukan sesuatu. Komitmen berwirausaha merupakan konsistensi tujuan yang akan dicapai oleh seorang wirausahawan dengan memegang prinsip-prinsip entrepreneurship (Rauf, 2020). Komitmen berwirausaha memiliki peranan penting dalam keberlangsungan sebuah usaha. Adanya komitmen yang dijalankan dalam menekuni berwirausaha didasarkan adanya keinginan untuk berhasil pada usaha. Komitmen dalam berwirausaha adalah suatu keterikatan diri dan keinginan yang kuat untuk membangun, memajukan, dan mempertahankan keberadaan usahanya dalam situasi apapun. Dalam membangun komitmen berwirausaha, diperlukan adanya kesabaran dan ketabahan; keinginan keras untuk maju; keuletan dan keyakinan yang kuat untuk maju.

\section{Strategi Bisnis}

Porter (1998) mengatakan untuk menghadapi suatu persaingan ada tiga jenis strategi yang dapat membantu memenangkan persaingan tersebut yaitu kepemimpinan biaya Differensiasi dan fokus. Porter menamakan ketiganya strategi persaingan generik (generic competitive strategies). Keunggulan biaya kemampuan perusahaan untuk merancang, membuat, dan memasarkan sebuah produk dengan cara yang lebih efisien dari pesaingnya. Sementara diferensiasi merupakan kemampuan untuk menyediakan produk unik atau memiliki kelebihan kepada pembeli dari segi kualitas. Sedangkan strategi Fokus menurut David (2011) berarti membuat produk dan menyediakan jasa yang memenuhi keperluan sejumlah kelompok kecil konsumen. Phongpetra \& Johri (2011) menemukan strategi fokus biaya lebih dominan mempengaruh kinerja pada aspek keuangan dan pemasaran, dibandingkan dengan strategi kepemimpinan biaya dan differensiasi biaya. Kulatunga (2008) menemukan bahwa hanya ada dua dari strategi generik yang berpengaruh terhadap kinerja UKM yaitu strategi kepemimpinan biaya dan strategi differensiasi. Lebih lanjut dijelaskan bahwa penerapan strategi kepemimpinan 


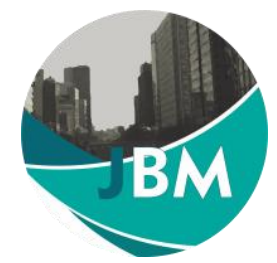

biaya dan strategi diferensiasi menimbulkan pertumbuhan penjualan lebih tinggi dan strategi kepemimpinan biaya dengan menggunakan pengurangan biaya mampu meningkatkan profitabilitas secara signifikan. Sejalan dengan penelitian Yan (2010) menemukan strategi biaya dan strategi differensiasi berpengaruh positif dan signifikan terhadap kinerja UKM secara keseluruhan. Strategi bisnis diperlukan khususnya dalam bidang usaha. Kemajuan usaha khususnya bidang UKM ditentukan dengan strategi yang digunakan oleh pemilik usaha. Strategi bisnis biasa diterapkan oleh usaha maupun perusahaan besar, sehingga hal ini memiliki peranan penting dalam keberlangsungan usaha.

\section{Kinerja Usaha}

Kinerja merupakan ukuran keberhasilan sebuah perusahaan dalam mencapai tujuannya. Kinerja merupakan hasil dari suatu proses yang mengacu dan diukur selama periode waktu tertentu berdasarkan ketentuan, standar atau kesepakatan yang telah ditetapkan sebelumnya (Lubis et al., 2018). Kinerja positif menunjukkan bahwa perusahaan dapat mencapai tujuan perusahaan, sebaliknya kinerja yang negatif berarti perusahaan tidak dapat mencapai tujuannya. Ukuran kinerja organisasi dapat berbentuk kuantitatif maupun kualitatif. Ukuran kinerja kuantitatif berupa capaian-capaian keuangan (ROE, ROA, ROI), produksi (jumlah barang terjual, rasio biaya operasional), pemasaran (jumlah pelanggan), dan efisiensi (Purnomo \& Lestari, 2010). Ukuran kinerja kualitatif berupa kedisiplinan, kualitas pencapaian tujuan, persepsi pimpinan terhadap capaian organisasi, perilaku individual dalam organisasi, dan efektivitas. Kinerja merupakan suatu kondisi yang harus diketahui dan dikonfirmasikan kepada pihak tertentu untuk mengetahui tingkat pencapaian hasil suatu instansi dihubungkan dengan visi yang diemban suatu organisasi atau perusahaan serta mengetahui dampak positif dan negatif dari suatu kebijakan operasional (Lubis et al., 2018). Najib \& Kiminami (2011) melakukan pengukuran kinerja bisnis UKM dengan menggunakan metode pengukuran subyektif meliputi volume penjulan, profitabilitas dan pangsa pasar. Kinerja sektor usaha mikro dan kecil dipengaruhi oleh dua faktor utama yaitu faktor-faktor eksternal seperti kebijakan pemerintah; ekonomi politik sosial budaya; dan faktor-faktor internal yang meliputi aspek sumber daya manusia, keuangan, dan pemasaran (Lesceviva, 2004; Toaha et al., 2019)

\section{Pengaruh Motivasi Berprestasi terhadap Komitmen Berwirausaha}

Lu et al., (2005) menemukan adanya pengaruh sikap, perilaku, dan motivasi berprestasi terhadap komitmen berwirausaha. Faktor-faktor tersebut telah memainkan peran terhadap ketekunan dan komitmen berwirausaha yang kuat untuk mencapai tujuan. Sementara Man et al. (2005) mengemukakan bahwa sikap, perilaku, dan motivasi berprestasi dapat mempengaruhi komitmen berwirausaha seseorang karena adanya pengaruh sosial, budaya dan ekonomi yang mendorong pengusaha melalui kegiatan yang berorientasi kewiraushaan untuk mencapai status sosial dan keberhasilan usaha. Dengan adanya dorongan untuk mencapai hasil yang terbaik, maka akan semakin memperkuat komitmen dalam menjalankan usaha.

H1. Motivasi berprestasi berpengaruh terhadap komitmen berwirausaha

\section{Pengaruh Efikasi diri terhadap komitmen berwirausaha}

Boekaerts et al. (2002) mengemukakan pentingnya efikasi diri sebagai faktor tambahan selain dari motivasi berprestasi dalam pembentukan komitmen. Selanjutnya hasil penelitian menemukan bahwa efikasi diri yang tinggi berpengaruh signifikan terhadap komitmen berwirausaha. Demikian juga hasil penelitian De Clercq, Benson, \& Martin (2012) menemukan efikasi diri wirausahawan berpengaruh positif terhadap komitmen berwirausaha. Semakin adanya efikasi diri pada pemilik usaha, dimana memiliki keyakinan dan percaya diri dengan usaha yang dilakukan, maka akan semakin memperkuat komitmen berwirausaha.

H2. Efikasi diri berpengaruh terhadap komitmen berwirausaha

\section{Pengaruh Komitmen Berwirausaha terhadap Kinerja Usaha}

Sahabudin (2012) menyatakan komitmen berwirausaha berpengaruh terhadap kinerja usaha. Komitmen yang tinggi ditunjukkan melalui kesediaan seseorang untuk menerima dan mempertahankan nilai-nilai dan tujuan kewirausahaan, yang didasarkan pada niat atau hasrat yang kuat, dorongan untuk bertindak, disiplin yang tinggi, dan keteguhan hati. Sehingga komitmen yang kuat dapat mengarahkan perilaku seseorang untuk menghasilkan kinerja atau prestasi. Carnahan, Agarwal, \& Campbell (2010) mengemukakan bahwa: komitmen merupakan faktor yang sangat penting dalam pencapaian kinerja dan daya saing. Hasil penelitian Emami \& Nazari, (2012) menunjukkan bahwa komitmen memiliki pengaruh yang kuat terhadap kinerja usaha. Terdapat beberapa 
penelitian yang mengkaji pengaruh percaya diri (self-esteem) dan komitmen berwirausaha terhadap kinerja serta menemukan bahwa komitmen berwirausaha dan percaya diri memiliki pengaruh terhadap kinerja.

H3. Komitmen berwirausaha berpengaruh terhadap kinerja usaha

\section{Komitmen berwirausaha memediasi pengaruh motivasi berprestasi terhadap kinerja usaha}

Mair \& Noboa (2005) melakukan penelitian terhadap 220 manajer menengah dengan mengkaji pengaruh efikasi diri terhadap perilaku wirausahawan dalam meningkatkan kinerja menemukan bahwa efikasi diri merupakan prediktor dari perilaku yang memiliki pengaruh terhadap kinerja usaha. Berdasarkan beberapa hasil penelitian tersebut bahwa motivasi berprestasi dan efikasi diri dapat mempengaruhi kinerja usaha melalui sikap dan perilaku melalui tindakan-tindakan yang berorientasi pada pencapaian prestasi atau kinerja dengan memanfaatkan kemampuan yang dimiliki. Sahabudin (2012) menyatakan motivasi berprestasi dan efikasi diri berpengaruh secara tidak langsung terhadap kinerja usaha rumput laut berskala kecil melalui komitmen berwirausaha.

H4. Komitmen berwirausaha memediasi pengaruh motivasi berprestasi terhadap kinerja usaha

\section{Komitmen berwirausaha memediasi pengaruh efikasi diri terhadap kinerja usaha}

Efikasi diri merupakan keyakinan yang dimiliki seseorang untuk mencapai tujuan yang diinginkan. Dengan adanya keyakinan yang dimiliki seseorang, maka akan meningkatkan motivasi untuk mencapai tujuan tersebut dan berdampak pada kinerja usaha. Adanya efikasi diri yang tinggi akan meningkatkan usaha untuk mencapai kinerja yang optimal. Efikasi diri juga memiliki pengaruh terhadap komitmen berwirausaha. Dengan adanya keyakinan yang kuat dalam menjalankan usaha dan memperoleh keuntungan, maka akan berdampak pula pada komitmen berwirausaha. Komitmen wirausaha yang tinggi karena adanya keterlibatan dan dorongan yang kuat dalam melakukan usaha. Hasil penelitian menunjukkan komitmen berwirausaha memediasi pengaruh efikasi diri terhadap kinerja UMKM. Dalam meningkatkan kinerja UMKM bisa dipengaruhi langsung dari nilai-nilai kewirausahaan, dalam hal ini efikasi diri, atau bisa juga efikasi diri akan meningkatkan komitmen berwirausaha terlebih dahulu pada pelaku usaha dan berdampak pada kinerja usaha.

H5. Komitmen berwirausaha memediasi pengaruh efikasi diri terhadap kinerja usaha

\section{Strategi bisnis memoderasi pengaruh komitmen berwirausaha terhadap kinerja usaha}

Parnell (2011) menemukan bahwa suatu organisasi yang berkinerja tinggi dengan mengunakan strategi kepemimpinan biaya harus menekankan pada efisiensi produksi. Temuan ini sejalan dengan penelitian (Ortega et al. (2010) yang menyatakan strategi kepemimpinan biaya berhubungan positif terhadap kinerja perusahaan, sementara Teeratansirikool (2013) menemukan kepemimpinan biaya mempengaruhi kinerja perusahaan melalui ukuran financial, peningkatan pangsa pasar Husnah (2013). Strategi bisnis memiliki peranan penting dalam keberlangsungan usaha. Dengan komitmen berwirausaha yang kuat yang dimiliki oleh pemilik UKM, maka akan berdampak pada meningkatnya kinerja usaha, dan strategi bisnis mampu memperkuat antar kedua pengaruh tersebut.

H5. Strategi bisnis memoderasi pengaruh komitmen berwirausaha terhadap kinerja usaha

\section{Metode Penelitian}

Penelitian ini menggunakan pendekatan kuantitatif dan termasuk dalam jenis penelitian explanatory research, yaitu penelitian bertujuan untuk menguji suatu teori atau hipotesis guna memperkuat atau bahkan menolak teori atau hipotesis hasil penelitian yang sudah ada sebelumnya. Penelitian ini dilaksanakan di kota malang khususnya di kecamatan lowokwaru pada pengusaha UMKM dengan jumlah responden 70 pengusaha umkm dari total jumlah 771 pengusaha UMKM. 70 responden didapatkan dengan menggunakan metode slovin tingkat eror 10\%. Definisi operasional pada penelitian ini adalah: motivasi berprestasi (X1), efikasi diri (X2), komitmen berwirausaha (Z1), strategi bisnis (Z2), dan kinerja usaha (Y). Teknik analisis data yang digunakan adalah menggunakan SmartPLS 3.0.

\section{Hasil Penelitian}

Uji validitas menggunakan convergent validity yang ditentukan dari nilai outer loading dari masing-masing variabel. Hasil pengujian validitas pada penelitian ini dilihat dari nilai outer loading yang dijelaskan pada gambar 1. Berdasarkan hasil pengujian validitas pada gambar 1 , hasil menunjukkan bahwa nilai outer loading dari masing-masing item lebih dari 0,5 sehingga menunjukkan valid. 
Jurnal Bisnis dan Manajemen
http://jurnal.unmer.ac.id/index.php/jbm/index
Volume 8 No 1

2021

HIm. 44 - 56

\section{Gambar 1. Hasil PLS Algorithm}

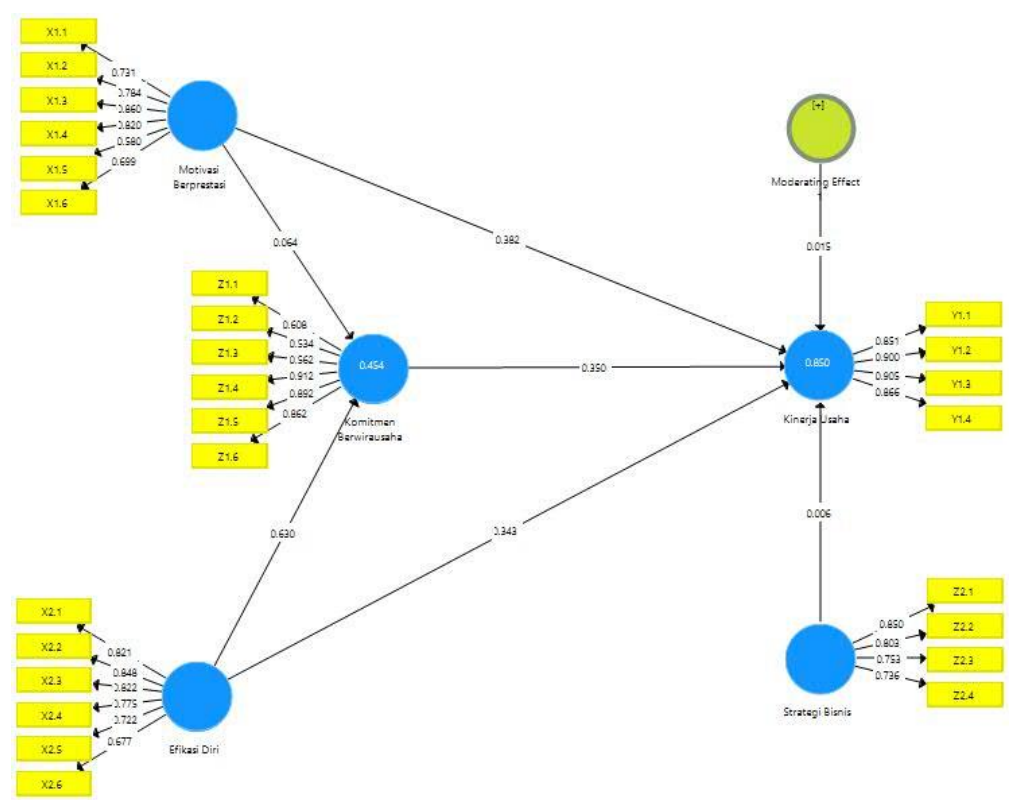

Sumber: Data diolah, 2020

Selanjutnya, hasil pengujian reliabilitas pada penelitian ini dijabarkan pada tabel 1 berikut:

Tabel 1. Pengujian AVE, Cronbach's Alpha, dan Composite Reliability

\begin{tabular}{lllll}
\hline Variabel & AVE & Cronbach's Alpha & Composite Reliability & Keterangan \\
Motivasi berprestasi & 0.564 & 0.844 & 0.884 & Reliabel \\
Kinerja usaha & 0.776 & 0.904 & 0.993 & Reliabel \\
Strategi bisnis & 0.619 & 0.798 & 0.866 & Reliabel \\
Komitmen berwirausaha & 0.557 & 0.843 & 0.878 & Reliabel \\
Efikasi diri & 0.608 & 0.870 & 0.902 & Reliabel \\
\hline
\end{tabular}

Sumber: Data primer diolah, 2020

Berdasarkan Tabel 1 nilai AVE pada masing-masing variabel memiliki nilai lebih dari 0.5 dan memenuhi persyaratan. Nilai Cronbach's Alpha masing-masing variabel juga memiliki nilai lebih besar dari 0.7 sehingga semua konstruk dari variabel tersebut dikatakan reliablel. Hasil Composite Reliability masing-masing variabel juga memiliki nilai lebih besar dari 0.7 sehingga dinyatakan reliabel.

\section{Pengujian Goodness of Fit Model}

Pengujian goodness of fit model dapat dilihat dari nilai predictive-relevance $\left(Q^{2}\right)$. Nilai $Q^{2}$ dihitung berdasarkan nilai $R^{2}$ dari masing-masing variabel endogen. Ghozali dan Latan (2015) menentukan kriteria kuat atau lemah sebuah model berdasarkan $Q^{2}$ adalah sebagai berikut: jika nilai $Q^{2} 0.35$ maka termasuk model kuat, jika nilai $Q^{2} 0.15$ maka termasuk model moderat, dan jika nilai $Q^{2} 0.02$ maka termasuk model lemah. Pengukuran variabel endogen komitmen berwirausaha memiliki nilai $R^{2}$ sebesar 0.454 dan pengukuran variabel endogen kinerja usaha diperoleh nilai $R^{2}$ sebesar 0.850 .

Dengan demikian nilai predictive-relevance $\left(\mathrm{Q}^{2}\right)$ diperoleh sebagai berikut:

$Q^{2}=1-\left(1-R_{1}^{2}\right)\left(1-R_{2}^{2}\right)$ 
$Q^{2}=1-(1-0.454)(1-0.850)$

$Q^{2}=0.918$

Berdasarkan perhitungan tersebut didapatkan nilai $Q^{2}$ sebesar 0.918 atau sehingga model struktural yang terbentuk dikatakan sangat baik karena mendekati nilai 1. Model variasi variabel dalam penelitian ini sebesar $91.8 \%$ dan sisanya $8.2 \%$ dijelaskan oleh variabel lain dan eror.

Penelitian ini dilakukan di UMKM Kota Malang di kecamatan Lowokwaru. Jumlah UMKM yang menjadi responden pada penelitian ini adalah 70 pengusaha UMKM. Karakteristik responden berdasarkan jenis kelamin didominasi oleh Perempuan sebanyak 63 orang dan laki-laki sebanyak 7 orang. Masa kerja dan berdirinya UKM didominasi sejak 5 tahun hingga sekarang. Hasil dari analisis data menjelaskan pengaruh antara motivasi berprestasi, efikasi diri terhadap kinerja usaha secara langsung maupun tidak langsung melalui mediasi dan moderasi ditunjukkan pada gambar 2 berikut:

\section{Gambar 2. Hasil analisis data menggunakan SmartPLS 3.0}

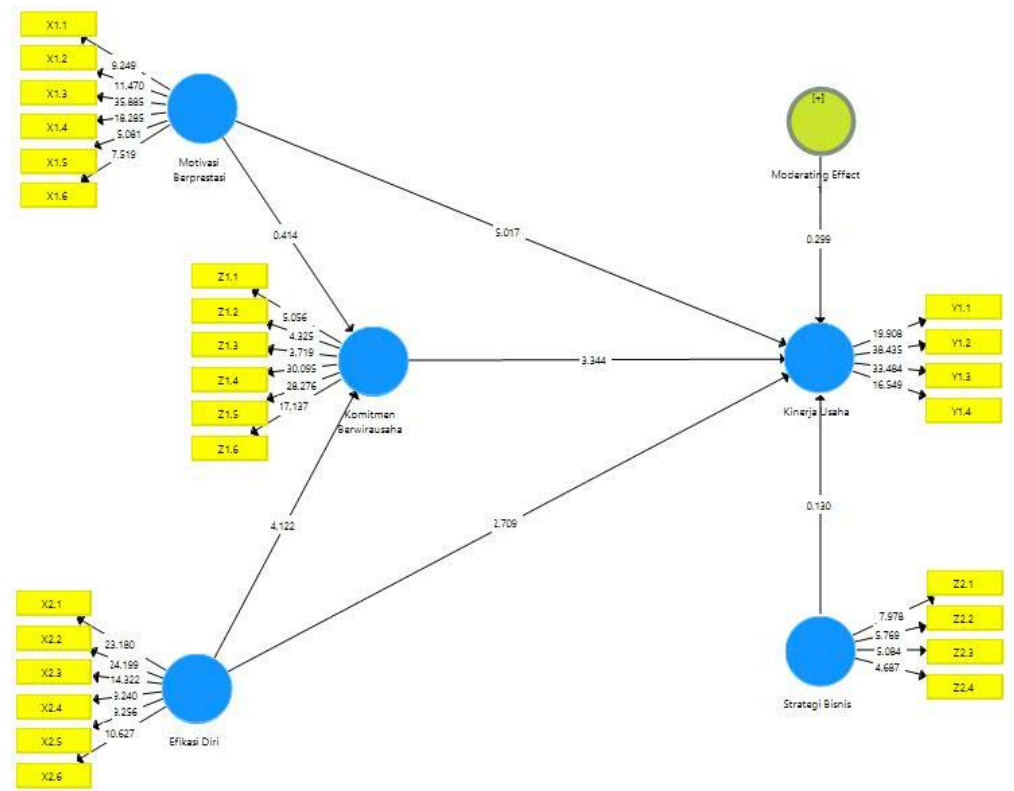

Sumber: Data diolah, 2020

Berikut hasil uji statistik pengaruh langsung disajikan pada tabel 2 berikut:

Tabel 2. Hasil Analisis Pengaruh Langsung

\begin{tabular}{clllll} 
H & Variabel Bebas & Variabel Terikat & t Statistik & p-value & Ket. \\
\hline 1 & Motivasi berprestasi & Komitmen berwirausaha & 0.408 & 0.684 & Tidak signifikan \\
2 & Efikasi diri & Komitmen berwirausaha & 3.843 & 0.000 & Signifikan \\
3 & Komitmen berwirausaha & Kinerja usaha & 3.242 & 0.001 & Signifikan \\
\hline
\end{tabular}

Sumber: Data diolah, 2020

Hasil pengujian pengaruh langsung antara motivasi berprestasi terhadap komitmen berwirausaha diperoleh nilai t-statistik 0.408 dan $p$-value 0.684 . karena nilai t-statistik $0.408<1.96$ dan $p$-value $0.684>0.05$ maka motivasi berprestasi berpengaruh tidak signifikan terhadap komitmen berwirausaha, sehingga $\mathrm{H} 1$ yang menyatakan bahwa motivasi berprestasi berpengaruh signifikan terhadap komitmen berwirausaha ditolak. Hasil pengujian pada hipotesis 2 yaitu pengaruh efikasi diri terhadap komitmen berwirausaha diperoleh nilai t-statistik $>1.96$ yaitu 3.843 dengan $p$-value 0.000 sehingga efikasi diri berpengaruh signifikan terhadap komitmen berwirausaha dan $\mathrm{H} 2$ diterima. Hasil pengujian langsung berikutnya adalah pengaruh komitmen berwirausaha terhadap kinerja usaha. Hasil menunjukkan t-statistik 3.242>1.96 dan p-value $0.001<0.05$ maka komitmen berwirausaha berpengaruh signifikan terhadap kinerja usaha sehingga $\mathrm{H} 3$ diterima.

Tabel 3. Hasil Pengujian Tidak Langsung

\begin{tabular}{lllllll} 
Jalur & Original Sample & Sample mean & Standard Deviation & $\mathrm{t}$ hitung & Sig & Ket. \\
\hline MB-KB-KU & 0.022 & 0.024 & 0.058 & 0.384 & 0.701 & Tidak signifikan
\end{tabular}




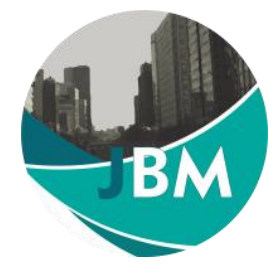

Jurnal Bisnis dan Manajemen

http://jurnal.unmer.ac.id/index.php/jbm/index

Volume 8 No 1

2021

HIm. 44 - 56
ED-KB-KU
0.220
0.223
0.088
2.493
0.013 Signifikan

Sumber: Data diolah, 2020

Berdasarkan hasil analisis pengaruh tidak langsung berdasarkan pengujian melalui SmartPLS 3 pada tabel 3 di atas, diketahui nilai $t$ hitung sebesar $0.384<1.96$ dan signifikansi $0.701>0.05$ sehingga dapat disimpulkan yaitu komitmen berwirausaha tidak memediasi motivasi berprestasi terhadap kinerja usaha. Hasil analisis menunjukkan bahwa pengaruh variabel motivasi berprestasi memiliki hasil tidak signifikan terhadap komitmen berwirausaha dan pengaruh komitmen berwirausaha terhadap kinerja usaha memiliki hasil signifikan. Sehingga komitmen berwirausaha dalam penelitian ini tidak memediasi sehingga $\mathrm{H} 4$ ditolak.

Komitmen berwirausaha memiliki peran mediasi antara pengaruh efikasi diri terhadap kinerja usaha. Hasil penelitian menunjukkan nilai signifikansi $0.013<0.05$ dan nilai t hitung $2.493>1.96$ sehingga $\mathrm{H} 5$ diterima. Efikasi diri memiliki pengaruh terhadap komitmen berwirausaha dan komitmen berwirausaha memiliki pengaruh terhadap kinerja usaha, sehingga komitmen berwirausaha sebagai partial mediation atau mediasi Sebagian.

\section{Pembahasan}

\section{Pengaruh Motivasi Berprestasi terhadap Komitmen Berwirausaha}

Penelitian ini mengkaji tentang bagaimana pengaruh nilai-nilai kewirausahaan berpengaruh terhadap kinerja UMKM. Pengukuran nilai-nilai kewirausahaan yang diteliti dalam penelitian ini adalah motivasi berprestasi dan efikasi diri karena merupakan nilai dominan dalam meningkatkan kinerja usaha. Berdasarkan teori motivasi adalah kecenderungan untuk bertindak suatu cara tertentu tergantung pengharapan sesuatu pada individu tertentu. Motivasi sebagai kekuatan yang diperlukan dan dicapai dalam waktu yang ditentukan. Motivasi juga mengacu pada dorongan dan tujuan perilaku. Dorongan seseorang dalam mencapai sesuatu dalam pencapaian prestasi dan terlibat dalam kegiatan secara inovatif dan bertanggung jawab akan hasil yang dicapai disebut dengan motivasi berprestasi. Motivasi berprestasi menurut McClelland (1987) adalah suatu pemikiran yang berhubungan dengan bagaimana melakukan sesuatu yang sebaik-baiknya bila dibandingkan dengan apa yang telah dilakukan sebelumnya dan lebih efisien dengan hasil yang maksimal. Begitu pun dalam dunia kewirausahaan. Motivasi berprestasi merupakan dorongan yang kuat dalam pencapaian tujuan dan berfokus pada peningkatan kinerja usaha. Mendol \& Marcus (2015) menyebutkan motivasi yang dicapai merupakan kekuatan untuk mencapai psikologis yang penting sehingga mempengaruhi berperilaku berwirausaha. Koh (1996) menjelaskan mengenai karakteristik kewirausahaan yang salah satunya menjelaskan mengenai motivasi berprestasi. Penelitian tersebut menjelaskan seseorang yang mempunyai motivasi berprestasi yang lebih tinggi daripada orang lain dan mempunyai hubungan yang kuat dalam niat berwirausaha.

Hasil pengujian secara langsung meneliti tentang pengaruh motivasi berprestasi terhadap komitmen berwirausaha. Hasil penelitian menunjukkan tidak adanya pengaruh antara motivasi berprestasi terhadap komitmen berwirausaha. Semakin kuat motivasi berprestasi yang dimiliki oleh pelaku usaha, maka tidak akan berpengaruh dan berdampak pada komitmen berwirausaha. Factor yang menyebabkan semakin kuatnya komitmen berwirausaha tidak hanya dipengaruhi oleh motivasi berprestasi saja, tetapi terdapat beberapa factor maupun indikator nilai kewirausahaan yang lain. Hasil penelitian ini tidak sejalan dengan penelitian yang dilakukan oleh (Lu et al., 2005) menemukan adanya pengaruh sikap, perilaku, dan motivasi berprestasi terhadap komitmen berwirausaha. Faktor-faktor tersebut telah memainkan peran terhadap ketekunan dan komitmen berwirausaha yang kuat untuk mencapai tujuan.

\section{Pengaruh Efikasi Diri terhadap Komitmen Berwirausaha}

Hasil pengujian menunjukkan adanya pengaruh signifikan antara efikasi diri terhadap komitmen berwirausaha. Efikasi diri merupakan suatu keyakinan diri maupun kepercayaan diri mengenai kemampuan yang dimiliki. Selain itu dengan adanya keyakinan diri tersebut maka akan memunculkan motivasi dalam melakukan sesuatu yang terbaik bagi usaha atau pekerjaan yang dilakukan. UMKM merupakan salah satu langkah awal yang dilakukan oleh pelaku usaha dalam memenuhi kebutuhan ekonomi. Dengan adanya motivasi yang kuat dan keyakinan yang tinggi, maka juga akan berdampak pada UMKM. Selain itu, komitmen yang tinggi dalam berwirausaha akan juga muncul seiring dengan adanya pengaruh efikasi diri yang kuat. Hasil penelitian juga menunjukkan adanya pengaruh antara efikasi diri terhadap komitmen berwirausaha, semakin kuat efikasi diri yang dimiliki, maka akan semakin meningkatkan komitmen pelaku usaha dalam berwirausaha dan tentu akan 
berdampak baik pula pada kinerja UMKM. Hasil penelitian ini sejalan dengan penelitian Fortune, Lee, \& Cavazos (2005) yang menemukan bahwa efikasi diri yang tinggi berpengaruh signifikan terhadap komitmen berwirausaha.

\section{Pengaruh Motivasi Berprestasi terhadap Kinerja UMKM Melalui Komitmen Berwirausaha}

Komitmen berwirausaha merupakan suatu dorongan atau keterlibatan dan keinginan yang kuat untuk membangun, memajukan, dan mempertahankan keberadaan usahanya dalam situasi apapun. Komitmen ini dimiliki oleh pelaku usaha yang menjalankan usaha dan berusaha menjaga keberlangsungan usaha tersebut. Factor komitmen berwirausaha dimunculkan dari diri sendiri maupun dari pihak lain yang mendukung adanya keberlangsungan organisasi. Adanya komitmen yang tinggi dalam menjalankan usaha, maka akan memberikan hasil yang baik pada kinerja UMKM. Hasil penelitian menunjukkan komitmen berwirausaha tidak memediasi pengaruh motivasi berprestasi terhadap kinerja UMKM. Hasil ini diperoleh karena tidak adanya pengaruh langsung anatra motivasi berprestasi terhadap komitmen berwirausaha dan adanya pengaruh langsung antara komitmen berwirausaha terhadap kinerja UMKM. Jika salah satu variabel eksogen maupun endogen tidak memiliki pengaruh pada variabel mediasi, maka dikatakan tidak memiliki peran mediasi. Terdapat beberapa hal yang dapat meningkatkan kinerja usaha, selain dari motivasi berprestasi. Self efficacy atau efikasi diri merupakan nilai-nilai kewirausahaan yang baik diterapkan pada pelaku usaha dalam menjalankan usaha bisnisnya.

\section{Pengaruh Efikasi Diri terhadap Kinerja UMKM Melalui Komitmen Berwirausaha}

Hasil pengujian langsung antara efikasi diri terhadap kinerja UMKM memiliki hasil yang signifikan dan berpengaruh. Semakin kuat atau tinggi efikasi diri yang dimiliki oleh pelaku usaha, maka akan semakin meningkatkan kinerja UMKM. Hal ini didasarkan karena adanya keyakinan pada diri dalam melakukan yang terbaik bagi usaha yang dijalankan, dan memiliki dampak pada kinerja usaha. Adanya efikasi diri yang tinggi akan meningkatkan usaha untuk mencapai kinerja yang optimal. Efikasi diri juga memiliki pengaruh terhadap komitmen berwirausaha. Dengan adanya keyakinan yang kuat dalam menjalankan usaha dan memperoleh keuntungan, maka akan berdampak pula pada komitmen berwirausaha. Komitmen wirausaha yang tinggi karena adanya keterlibatan dan dorongan yang kuat dalam melakukan usaha. Hasil penelitian menunjukkan komitmen berwirausaha memediasi pengaruh efikasi diri terhadap kinerja umkm. Hasil pengujian mediasi ini menjadikan komitmen berwirausaha sebagai partial mediation atau mediasi Sebagian. Hal ini dikarenakan adanya pengaruh langsung antara efikasi diri terhadap komitmen berwirausaha, dan adanya pengaruh antara efikasi diri terhadap komitmen berwirausaha dan komitmen berwirausaha terhadap kinerja umkm. Dalam meningkatkan kinerja umkm bisa dipengaruhi langsung dari nilai-nilai kewirausahaan, dalam hal ini efikasi diri, atau bisa juga efikasi diri akan meningkatkan komitmen berwirausaha terlebih dahulu pada pelaku usaha dan berdampak pada kinerja usaha.

\section{Pengaruh Komitmen Berwirausaha terhadap Kinerja UMKM}

Berdasarkan hasil pengujian menunjukkan adanya pengaruh signfikan antara komitmen berwirausaha terhadap kinerja UMKM. Hal ini menunjukkan bahwa dengan adanya komitmen yang tinggi dalam wirausaha, yang didasarkan pada niat atau hasrat yang kuat, dorongan untuk bertindak, disiplin yang tinggi, dan keteguhan hati. Sehingga komitmen yang kuat dapat mengarahkan perilaku seseorang untuk menghasilkan kinerja atau prestasi, utamanya kinerja UMKM. Jika seseorang memiliki keterlibatan dan keterikatan yang tinggi pada usaha yang dijalankan, maka akan berdampak pada kemajuan usaha utamanya adalah kinerja usaha. Penelitian dengan hasil serupa juga dilakukan oleh Sahabudin (2012) yang menemukan adanya komitmen yang tinggi pada usaha akan memberikan dampak bagi kinerja UMKM sehingga komitmen wirausaha memiliki pengaruh signifikan terhadap kinerja UMKM.

\section{Pengaruh Komitmen Berwirausaha terhadap Kinerja UMKM Dengan Strategi Bisnis Dalam Moderasi}

Hasil pengujian langsung menunjukkan adanya pengaruh signifikan antara komitmen berwirausaha terhadap kinerja UMKM. Dengan tingginya dan kuatnya berkomitmen dalam menjalankan sebuah usaha, maka akan semakin meingkatnya kinerja UMKM. Strategi bisnis merupakan salah satu cara dalam meningkatkan kinerja usaha. Porter (1998) mengatakan untuk menghadapi suatu persaingan ada tiga jenis strategi yang dapat membantu memenangkan persaingan tersebut yaitu kepemimpinan biaya, Differensiasi, dan fokus. Dalam hal ini, strategi bisnis dijadikan sebagai moderasi antara komitmen berwirausaha terhadap kinerja UMKM. Penelitian ini mengkaji apakah strategi bisnis memperkuat atau memperlemah pengaruh tersebut. Hasil penelitian menunjukkan bahwa strategi bisnis tidak memoderasi pengaruh komitmen berwirausaha terhadap kinerja UMKM sehingga tidak memiliki peran dalam kedua pengaruh tersebut. Strategi bisnis biasanya digunakan pada usaha atau perusahaan dengan skala yang besar, dan pada penelitian ini menggunakan objek denga skala kecil 


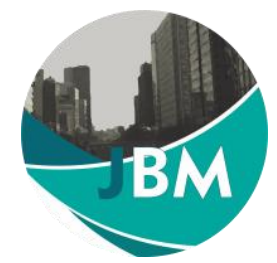

(UMKM) sehingga strategi bisnis tidak digunakan. Selain itu, objek penelitian ini hanya dilakukan pada satu tempat wilayah sehingga lebih menekankan pada komitmen berwirausaha secara langsung untuk meningkatkan kinerja usaha. Selain itu temuan dari Kaya (2015) menyatakan strategi kepemimpinan biaya tidak berpengaruh terhadap kinerja UKM, penerapan strategi perlu memperhatikan karakteristik dan kemampuan organisasi.

\section{Kesimpulan dan Saran}

Berdasarkan hasil analisis dan pembahasan, maka dapat diambil kesimpulan yaitu: Motivasi berprestasi tidak berpengaruh terhadap komitmen berwirausaha. Hal ini menjelaskan bahwa komitmen berwirausaha tidak didasari oleh adanya motivasi berprestasi. Komitmen berwirausaha merupakan dorongan yang kuat untuk selalu memberikan keterlibatan aktif pada usaha. Efikasi diri berpengaruh terhadap komitmen berwirausaha. Semakin kuat keyakinan diri untuk memberikan yang terbaik bagi usahanya, maka akan semakin kuat komitmen dalam menjalankan usaha. Komitmen berwirausaha berpengaruh terhadap kinerja usaha. Semakin kuat komitmen yang dimiliki pelaku usaha, maka akan semakin meningkatkan kinerja usaha untuk keberlangsungan dan keberlanjutan usaha. Komitmen berwirausaha tidak memediasi pengaruh motivasi berprestasi terhadap kinerja usaha. Komitmen berwirausaha memediasi pengaruh efikasi diri terhadap komitmen berwirausaha. Strategi bisnis tidak memoderasi pengaruh komitmen berwirausaha terhadap kinerja usaha. Strategi bisnis digunakan dalam kegiatan usaha dengan lingkup yang besar, dan untuk usaha mikro kecil lebih menekankan pada komitmen berwirausaha untuk meningkatkan kinerja usaha.

Bagi peneliti selanjutnya, dapat memperluas cakupan objek penelitian. Selain itu, dapat meneliti maupun menambahkan variabel lain dalam meneliti tentang nilai-nilai kewirausahaan. Penelitian selanjutnya dapat mengukur sejauh mana kinerja karyawan maupun strategi usaha. Kemudian UKMM yang dikelola diharapkan mampu meningkatkan nilai-nilai kewirausahaan, utamanya dalam motivasi berprestasi. Adanya dorongan yang kuat dalam berprestasi, utamanya dalam pancapaian keuntungan akan berdampak baik bagi keberlangsungan usaha serta UKM diharapkan mampu meningkatkan dan memperbaiki strategi bisnis yang diterapkan untuk usahanya.

\section{Daftar Pustaka}

Azhar, A., Javaid, A., Rehman, M., \& Hyder, A. (2014). Entrepreneurial Intentions among Business Students in Pakistan. Journal of Law and Governance, 5(2). https://doi.org/10.15209/jbsge.v5i2.181

Batista, P. C. de S., Lisboa, J. V. de O., Augusto, M. G., \& Almeida, F. E. B. de. (2016). Effectiveness of business strategies in Brazilian textile industry. Revista de Administração [RAUSP], 51(2), 225-239.

Carnahan, S., Agarwal, R., \& Campbell, B. (2010). The Effect of Firm Compensation Structures on the Mobility and Entrepreneurship of Extreme Performers. Business, 902(December 2009), 1-43. https://doi.org/10.1002/smj

Darmawan, D. (2020). Profesionalisme, Motivasi Berprestasi, Komitmen Organisasi Dan Pengaruhnya Terhadap Intensi Berwirausaha. EKUITAS (Jurnal Ekonomi dan Keuangan), 3(3), 344-364. https://doi.org/10.24034/j25485024.y2019.v3.i3.4167

David, F. R. (2011). Manajemen Starategik. Jakarta: Salemba Empat.

De Clercq, D., Benson, H., \& Martin, B. (2012). The roles of learning orientation and passion for work in the formation of entrepreneurial intention. International Small Business Journal, 1-25.

Dinis, A., Ferreira, J., Paco, A., Mario., R., \& Rodrigues, R. G. (2013). Psychological Characteristics and Entrepreneurial Intentions among Secondary Students. Education and Training, 55(8-9), 763-780.

Ebitu, \& Ezekiel, T. (2016). Marketing Strategies And The Performance Of Small And Medium Enterprises In Akwa Ibom State, Nigeria, British Journal of Marketing Studies. European Centre for Research Training and Development UK, 4(5), 61-62.

Emami, M., \& Nazari, K. (2012). SSRN-id2083390. 1(11), 59-69. 
EP, O., JF, A., \& EC, C. (2010). Competitive Strategy, Structure And Firm Performance: A Comparison Of The Resource-Based View And The Contingency Approach. Management Decision, 48(8), 1282-1303.

Fortune, A. E., Lee, M., \& Cavazos, A. (2005). Achievement Motivation and Outcome In Social Work Field Education. Washington.

Hakim, L. (2019). Dinas Koperasi dan UKM Kota Malang Beber Kelemahan UMKM hingga Sulit Berkembang. Diambil dari https://www.malangtimes.com/baca/37544/20190329/151300/dinas-koperasi-dan-ukm-kotamalang-beber-kelemahan-umkm-hingga-sulit-berkembang

Hakimpoor, H. (2014). Strategic Planning Process Dimensions and SMEs Performance. Proceedings of 10th Global Business and Social Science Research Conference.

Husnah. (2013). Aset Tanwujud, Strategi Bersaing, Dan Kinerja Keuangan, Kajian Pada UKM Rotan Di Kota Palu Sulawesi Tengah. Universitas Brawijaya Malang.

Kasmir. (2017). Kewirausahaan. Jakarta: PT.Raja Grafindo Persada.

Kaya, N. (2015). Corporate Entrepreneurship, Generic Competitive Strategies, and Firm Performance in Small and Medium-Sized Enterprises. Procedia Social and Behavioral Sciences, 662 - 668.

Kementrian Koperasi dan Usaha Kecil dan Menengah. (2018). Perkembangan Data Usaha Mikro, Kecil, Menengah (Umkm) Dan Usaha Besar (Ub) Tahun 2017 - 2018. Diambil dari http://www.depkop.go.id/dataumkm

Kickul, J., \& Gundry, L. (2002). <1540-627X.00042.pdf>. Journal of Small Business Management, 40(2), 85-97.

Kimatu, D. K., \& Bichanga, O. W. (2014). Competitive Strategies and the Non Financial Performance of Micro Enterprises in Kenya, (Survey of Industrial Knitting Micro Enterprises in Kiambu County),. International Journal of Management and Commerce Innovations, 2(2), 160-186.

Koh, H. C. (1996). Testing Hypotheses of Entrepreneurial Characteristics: A study of Hong Kong MBA Students. Journal of Managerial Psychology, 11(3), 1225.

Kulatunga, D. (2008). Electronic Commerce Strategies, Generic Strategies, and Firm Performance: A Study of Small and Medium Enterprises in Aichi, Japan. Japanese Journal of Administrative Science, 21(1), 27-46.

Lesceviva, M. (2004). Rural Entrepreneurship Success Determinant. Latvian University of Agriculture, Eksjo, Latvia.

Lu, C. Q., Siu, O. L., \& Cooper, C. L. (2005). Managers' occupational stress in China: The role of self-efficacy. Personality and Individual Differences, 38(3), 569-578. https://doi.org/10.1016/S0001-4575(03)00016-2.

Lubis, Y., Hermanto, B., \& Edison, E. (2018). Manajemen dan Riset Sumber Daya Manusia. Bandung: Alfabeta.

Luthans, F. (2006). Perilaku Organisasi edisi sepuluh. Yogyakarta: Andi.

Mair, J., \& Noboa, E. (2005). Social Entrepreneurship: How Intentions to Create a Social Enterprise Get Formed. SSRN Electronic Journal, 3(521). https://doi.org/10.2139/ssrn.462283

McClelland, D. . (1987). The Achievement Motive. New York Appleton: Century Crolts Inc.

Mendol, P. C., \& Marcus. (2015). A Pattern Analysis of Student's Achievement Goals. Journal of Educational Psychology, 85(4), 582-590.

Najib, M., \& Kiminami, A. (2011). Innovation, cooperation and business performance: Some evidence from Indonesian small food processing cluster. Journal of Agribusiness in Developing and Emerging Economies, 1(1), 75-96. https://doi.org/10.1108/20440831111131523

Nyariki, R. N. (2013). Strategic Management Practices As A Competitive Tool In Enhancing Performance Of Small and Medium Enterprose In Kenya, A research Project Submitted In Partisal Fullfillment Of The Requirements For The Award Of The Business Administration. University Of Nairobi.

Parnell, J. A. (2011). Strategic Capabilities, Competitive Strategy, And Performance Among Retailers In Argentina, Peru And The United States. Management Decision, 49(1), 130-155.

Phongpetra, V., \& Johri, L. M. (2011). Impact of business strategies of automobile manufacturers in Thailand. 
International Journal of Emerging Markets.

Porter, M. E. (1998). On Competition. Boston: Harvard Business School.

Purnomo, R., \& Lestari, S. (2010). Pengaruh Kepribadian, Self-Efficacy, Dan Locus of Control Terhadap Persepsi Kinerja Usaha Skala Kecil Dan Menengah. Jurnal Bisnis dan Ekonomi (JBE), 17(2), 144-160.

Rauf, R. (2020). Pengaruh Karakteristik Individu Dan Komitmen Berwirausaha Terhadap Kinerja Usaha Penangkapan Ikan Laut. SEIKO: Journal of Management \& Business, 3(2), 92. https://doi.org/10.37531/sejaman.v3i2.594

Robbins, S. P., \& Judge, T. A. (2015). Perilaku Organisasi edisi 16. Jakarta: Salemba Empat.

Sahabudin, R. (2012). Perkembangan Nilai-Nilai Kewirausahaan dalam Meningktakan Kinerja Usaha Rumput Laut Skala Kecil. Trikonomika, 11(1), 81-95.

Suryana. (2017). Kewirausahaan: Pedoman Praktis, Kiat dan Proses Menuju Sukses. Bandung: Salemba Empat.

Teeratansirikool, L. (2013). Competitive strategies and firm performance: The mediating role of performance measurement. International Journal of Productivity and Performance Management, 62(2).

Toaha, M., Maupa, H., Brasit, N., Taba, I., \& Aswan, A. (2019). Competitive Sustainability of Food and Beverage SMEs in South Sulawesi. 92(Icame 2018), 608-615. https://doi.org/10.2991/icame-18.2019.64

Wulandari, S. (2013). Pengaruh Efikasi Diri Terhadap Minat Berwirausaha Pada Siswa Kelas XII Di SMK Negeri Surabaya. Fakultas Ekonomi, Unesa, Kampus Ketintang Surabaya, 1(1), 1-20. Diambil dari https://jurnalmahasiswa.unesa.ac.id/index.php/jptn/article/viewFile/1902/5311

Yan, S. (2010). Competitive Strategy and Business Environment: The Case of Small Enterprises in China. Canadian Center of Science and Education, Asian Social Science, 6(11).

Zimmerer, Thomas, W., Scarborough, M, N., \& Wilson, D. (2009). Kewirausahaan dan Manajemen Usaha Kecil. Jakarta: Salemba Empat. 